\title{
Caregivers of People with Neurodegenerative Diseases: Profile and Unmet Needs from a Population-Based Survey in South Australia
}

\author{
Samar Aoun, M.P.H., B.Sc., Ph.D., Ruth McConigley, BNurs, Ph.D., Amy Abernethy, M.D., \\ and David C. Currow, BMed, M.P.H. ${ }^{3}$
}

\begin{abstract}
Introduction: Neurodegenerative diseases (NDD) are characterized by progressive decline and loss of function, requiring considerable third-party care. NDD carers report low quality of life and high caregiver burden. Despite this, little information is available about the unmet needs of NDD caregivers.

Methods: Data from a cross-sectional, whole of population study conducted in South Australia were analyzed to determine the profile and unmet care needs of people who identify as having provided care for a person who died an expected death from NDDs including motor neurone disease and multiple sclerosis. Bivariate analyses using $\chi^{2}$ were complemented with a regression analysis.

Results: Two hundred and thirty respondents had a person close to them die from an NDD in the 5 years before responding. NDD caregivers were more likely to have provided care for more than 2 years and were more able to move on after the death than caregivers of people with other disorders such as cancer. The NDD caregivers accessed palliative care services at the same rate as other caregivers at the end of life, however people with an NDD were almost twice as likely to die in the community (odds ratio [OR] 1.97; 95\% confidence interval [CI] 1.30 to 3.01) controlling for relevant caregiver factors. NDD caregivers reported significantly more unmet needs in emotional, spiritual, and bereavement support.

Conclusion: This study is the first step in better understanding across the whole population the consequences of an expected death from an NDD. Assessments need to occur while in the role of caregiver and in the subsequent bereavement phase.
\end{abstract}

\section{Introduction}

$\mathbf{P}$ EOPLE LIVING WITH a neurodegenerative disease (NDD) such as motor neuron disease (MND), multiple sclerosis (MS), or dementia face many long-term challenges. These diseases are progressive, often with a stepwise decline in function. ${ }^{1}$ People with an NDD often face long periods of dependency as physical function decreases. There are no cures for these NDD and treatment aims to palliate symptoms and optimize function and comfort. ${ }^{2,3}$

Principal NDD caregivers are a partner/spouse between $79 \%{ }^{4}$ and $94 \%{ }^{5}$ of the time. In these studies, other family members and close friends also took on caregiving roles. Caregiver demographic characteristics relate, in part, to the nature of the NDD; for example, caregivers of people with MS are more likely to be young males or a nonspousal family member, because MS occurs more commonly in young women. ${ }^{6}$

NDD caregiver quality of life has been reported to be low ${ }^{7,8}$ and is inversely proportional to caregiver burden. ${ }^{9}$ This may be related to uncertainty of timelines for disease progression in $\mathrm{NDD}^{10}$ and limited support services. ${ }^{11}$ NDD caregivers suffer significant distress in their roles. Sleep deprivation and fatigue are common, as are anxiety, anger and isolation. ${ }^{12,13}$ NDD caregivers undertake a considerable number of personal care tasks (toileting, bathing, and dressing) and instrumental tasks (managing finances) from relatively early in the disease trajectory. ${ }^{14}$ They also play a key role in providing social and emotional support for the person with NDD. ${ }^{6,15}$ Caregivers may suffer financial hardship, ${ }^{16}$ changes to family roles and relationships, ${ }^{17}$ and social isolation. ${ }^{14,18}$ As a result, both

\footnotetext{
${ }^{1}$ WA Center for Cancer and Palliative Care, Curtin University of Technology, Perth, Western Australia, Australia.

${ }^{2}$ Department of Medicine-Medical Oncology, Duke University Medical Center, Durham, North Carolina.

${ }^{3}$ Department of Palliative and Supportive Services, Flinders University, Adelaide, South Australia, Australia.

Accepted January 6, 2010.
} 
patients with NDD and their caregivers report lower quality of life compared to their contemporaries. ${ }^{19}$

Despite the growing body of literature describing the stressors associated with caring for someone with an NDD, there is limited information about their needs at a population level. Several studies ${ }^{16,20}$ have identified the information needs (illness and disease progression ${ }^{17}$ ) for caregivers of someone with an NDD as well as assistance with home duties, meal preparation or cleaning but were unable to access these services. ${ }^{21,22}$ Several authors reported that health professionals appeared to have limited understanding of NDD and were ill-prepared to provide information to families. ${ }^{16,17}$

The aim of this study was to apply a whole-of-population approach to explore differences in the profile, service use, and experiences of bereaved caregivers who had someone close to them die from an NDD.

\section{Methods}

The South Australian Health Omnibus is an annual, faceto-face, cross-sectional, whole-of-population, multistage, systematic area sampling survey, which provides an opportunity to assess the population rather than people identified by health services. ${ }^{23}$ Omnibus is run by a commercial research organization that provides deidentified data for researchers on a user-pays basis. Questions in the Omnibus change each year in accordance with the needs of the end- users. Approximately 200 questions are asked of each participant in an interview lasting 60 to 90 minutes in their own home. Interviews include demographic questions and cover areas of health beliefs and health behaviors. Table 1 lists question included in the Omnibus for the years data were collected on end-of-life care by this research group. Questions on caregiver unmet needs were included in 2002-2003 and 2005-2007. Only the bereaved were asked questions about unmet needs.

\section{Sample and Setting}

The Omnibus survey is carried out between September and December each year in the Australian state of South Australia. South Australia has a population of 1.56 million people $(7 \%$ of the Australian population), the majority of whom live in one metropolitan center. ${ }^{24}$

A stratified random sampling method was used to identify a representative sample from metropolitan and rural areas of South Australia. The strata used are census collection districts, each of which contains approximately 200 dwellings. In the metropolitan area 340 of a total 2041 collection districts are randomly sampled. One hundred of a total 1010 rural collector districts are chosen in proportion to the size of the town. Properties to be approached are then selected randomly using a computer generated random starting point and a skip pattern selecting every fourth property.

Table 1. Questions Asked About Palliative and End-of-Life Care in the South Australian Health Omnibus 2000-2007, a Face-to-Face Whole-of-Population Survey

\begin{tabular}{|c|c|}
\hline Core questions 2000-2007 ( $\mathrm{n}=23588)$ & Additional end-of-life/palliative are questions asked \\
\hline Demographics ${ }^{\# \#}$ & $2001-2007(n=20561)$ \\
\hline 1. of the respondent & Most involved level of care; \\
\hline $\begin{array}{l}\text { - age, } \\
\text { - gender, } \\
\text { - country of birth }\end{array}$ & $\begin{array}{l}\text { - day-to-day hands-on care (5-7 days per week) } \\
\text { - intermittent hands-on care ( } 2-4 \text { days per week) } \\
\text { - rare hands-on care ( } 1 \text { or less days per week) }\end{array}$ \\
\hline - marital status & Time since death; \\
\hline - highest level of education & Relationship to the deceased; \\
\hline - rural/metropolitan residence & Expectations between diagnosis and death; \\
\hline - current work status ${ }^{\#}$ & Ability to 'move on' with life; \\
\hline 2. of the household annual gross income & Why a palliative care service was not used \\
\hline Questions specific to end-of-life issues & $2002-3,2005-7(n=14539)$ \\
\hline $\begin{array}{l}\text { 1. Did the person know someone close to them who died in } \\
\text { the last } 5 \text { years of an 'expected' death?* }\end{array}$ & Perceived unmet needs \\
\hline 2. The cause of death & $2003(n=2999)$ \\
\hline \multirow[t]{5}{*}{ 3. Whether a palliative care service was used ${ }^{* *}$} & Financial burden of caregiving \\
\hline & $\begin{array}{l}\text { 2003-7 }(n=14509) \\
\text { Length of time care for which care was provided }\end{array}$ \\
\hline & $\begin{array}{l}2004(n=3051) \\
\text { Level of comfort in the last two weeks of life }\end{array}$ \\
\hline & $\begin{array}{l}2004-6(n=9001) \\
\text { Place of death; } \\
\text { Use of bereavement services; } \\
\text { Age of the person who died }\end{array}$ \\
\hline & $\begin{array}{l}2006-7(\mathrm{n}=5476) \\
\text { Would you take on the caregiving role again? }\end{array}$ \\
\hline
\end{tabular}

*Gateway question to the section on end-of-life/palliative care. If the answer was 'no' the respondent moved onto the next section of the survey.

${ }^{* *}$ Always asked at the end of the questions to ensure that palliative care issues were not pre-empted.

${ }^{*}$ not asked in $2006(\mathrm{n}=2969)$.

\#\# researchers have no influence over these questions.

indicates data used in this study. 
Annually, residents from more than 5000 properties are approached to participate. Properties approached were not always residential; some may be vacant land or businesses. Participation rates are calculated on the number of potential participants not the number of properties. Using a trained interviewer, one interview was conducted per household with a person over the age of 15 who most recently had a birthday.

\section{Data quality}

All data were double entered. Missing responses were followed up by telephone. For quality assurance, $10 \%$ of respondents were re-contacted and asked to confirm their eligibility and reanswer a subset of questions. Aggregated data were anonymised before release to researchers.

\section{Statistical analysis}

Data were weighted by the inverse of the respondent's probability of selection for the survey, adjusted for participation rates in metropolitan and rural areas and then reweighted and directly standardized against South Australia's population (2006) for gender, 10 year age group, country of birth, and region of residence (urban, suburban, outer metropolitan, regional, rural and remote). Using unweighted data, there were no statistically significant differences in demographics between the years confirmed before consolidating data. Direct standardization macros ${ }^{25}$ appropriate for combining more than 1 survey year were applied. ${ }^{26,27}$ Each respondent was assigned a standardized weight. Only weighted data were analyzed.

Descriptive statistics were used for respondents' demographic characteristics. Bivariate analyses to define demographic characteristics for the bereaved, the deceased and service use used $\chi^{2}$ and subsequently for the subgroup of active caregivers. Multifactor analysis used logistic regression by incorporating plausible variables. Analyses were complete using PWAS version 17.0 software (SPSS Corporation, Chicago, IL).

\section{Sensitivity analyses}

To confirm the direction and magnitude of the findings, all analyses were re-run with the unweighted data.

\section{Ethics and consent}

The Omnibus survey receives annual approval from the South Australian Department of Health Research Ethics Committee. Verbal consent was obtained from participants before interview, and participation accepted as continued consent.

\section{Results}

Among the population who experienced an expected death in the 5 years before their survey response (Fig. 1), 230 respondents had someone close to them die of an NDD (the bereaved). Table 2A compares the demographic characteristics, caregiving profile, and palliative care service use of the NDD bereaved and all other diagnoses (of which cancer accounted for $82 \%$ ). The two groups did not differ in demographic characteristics except for a smaller proportion of NDD bereaved whose place of birth was not an Englishspeaking country (3.5\% versus $9.5 \%$ ).
For all NDD bereaved, there were no significant differences in the caregiving role profile; however, more NDD bereaved had someone close to them who had received care for two or more years (52\% versus 39\%), more of the respondents from the NDD group were able to "move on" with life after the death of the ill person ( $96 \%$ versus $92 \%$ ) and for $42 \%$ of people with NDD, place of death was in the community (home or residential aged care facility) compared to $27 \%$ for people with other diagnoses. Given that "place of death" was only asked in 3 years $(n=94$ caregivers of people with NDD), a limited number of factors could be included in a regression analysis. Four dichotomous factors were included in the final regression analysis: place of death, and carer characteristics (gender; age [ $<65 / 65+$ ); highest level of education [school/ postschool); and country of birth [English speaking/nonEnglish speaking)). The model confirmed that controlling for the respondents' demographic factors, community-based death was much more likely for people with NDD than for other diagnoses (odd ratio [OR] 1.97; 95\% confidence interval [CI] 1.30 to 3.01). For this analysis, the Hosmer and Lemeshow goodness of fit $(p=0.939)$ suggested that the model adequately fits the data and the Omnibus Tests of Model coefficients ( $p=0.028)$ confirmed this. The Nagelkerke $R^{2}$ was 0.018 .

Twenty-two percent of respondents identified themselves as active caregivers, providing "day-to-day," "intermittent," or "rare" hands-on care. Spouses provided $10 \%$ of care to the NDD group. An analysis compared active caregivers of people with NDD $(n=55)$ to all other life-limiting diagnoses ( $n=1973$; Table 2B). This evaluates people who self-identify as providing practical caregiving support for the decedent. The trend for higher rates of community-based death was also seen in this subgroup. Of concern, the most significant difference noticed between the two groups was the caregivers' perceptions of less comfort in the last 2 weeks of life for people dying from NDD.

For unmet needs, the significant difference (Table 3) related to emotional, spiritual, or bereavement support, where $36 \%$ of the carers of someone with an NDD reporting an unmet need compared to $24 \%$ of the other groups combined. All other perceived unmet needs were similar for the two groups. Only one third of active caregivers reported having enough support.

\section{Discussion}

The unmet needs for emotional, spiritual, or bereavement support were greater for carers of people with neurodegenerative diseases, despite access to palliative care services being equal to other groups with life-limiting illnesses. Place of death was more likely to be in the community, but perceived discomfort for the person dying was greater for caregivers of a person with a NDD than for other diagnoses.

A contrast to previously published literature was the proportion of caregivers for a person with an NDD diagnosis who were not the partner/spouse of the person. Only $10 \%$ of the sample in this study was spousal. This is in contrast to other studies that found that more than $70 \%$ of caregivers were the spouse/partner of the person requiring care. ${ }^{4}$ This difference is directly as a result of who is asked the question: if one asks the person with the NDD who their principal caregiver is, they are most likely to answer that it is their spouse or partner; if one directs the question to people in the community about whether they helped to provide care for someone with a NDD 


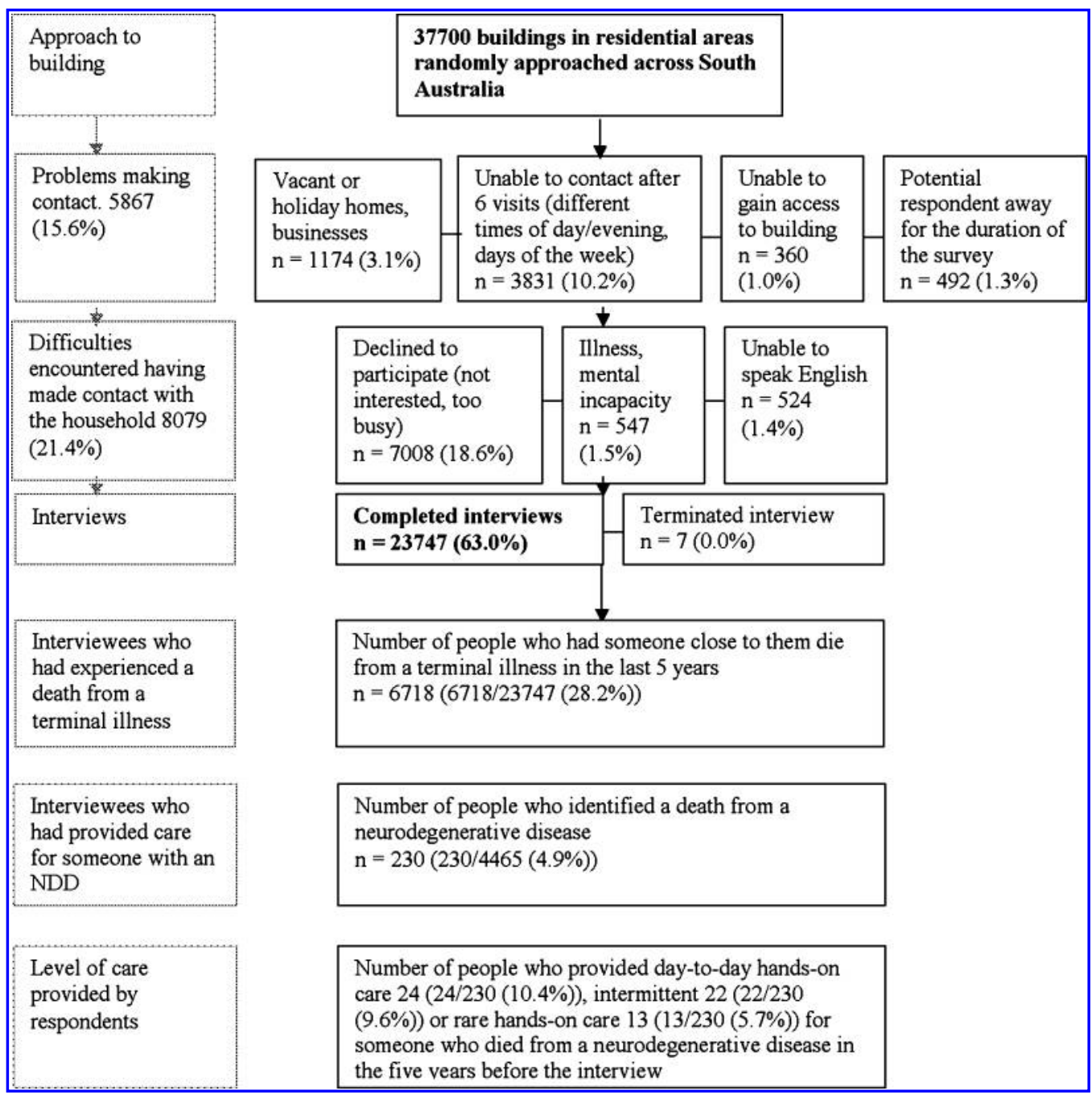

FIG. 1. Flow chart of sampling strategy to identify neurogenerative disease (NDD) caregivers.

(this current survey), there are likely to be a number of people for each decedent who answer "yes" to this question given the large size of caring networks that develop over long periods of time to support people. Having a network of such caregivers may be reflected in the higher proportion of people with NDD who die in the community and may be a consequence of a longer disease trajectory that allows networks of close friends and family to form.

Half of NDD caregiver respondents stated that specialist palliative care services (SPCS) were used. This was not seen in the only other Australian literature on NDD caregivers. ${ }^{13,28}$ Fewer than $10 \%$ of people who died of nonmalignant diseases had accessed SPCS, compared with $66 \%$ of people who died of cancer. $^{28}$ These differences in SPCS uptake reflect local referral patterns because of local service structures, professional relationships and local clinical champions. Although 1 in 2 people with a life-limiting illness is referred to a SPCS, the diagnostic subgroups who comprise this referral base differ widely from service to service. For example, in South Australia $70 \%$ of people who die from MND in the state are seen by a specialist palliative care team with specific resources in MND management including airways management, swallowing assessment and nutritional assessment because there is a local champion with a clinical interest in this clinical area. Despite differences in local referral patterns, the data about caregivers from this survey can be generalized because it is generated independently of any health service accessed because caregivers are contacted directly in the community. It would not be possible to generalize the uptake of SPCS from these data.

Unmet needs in the areas of emotional, spiritual and bereavement support were reported by more than one third of the NDD caregivers, suggesting that the impact of caregiving affects a wide group of family and friends of the deceased. The prolonged distress of watching the functional physical decline of someone close is often a life-changing experience. How health and social services should best respond to such distress is not yet clear.

People with NDD identified in this study were more likely to die in community-based care than people with other illnesses. These findings are similar to those of a Western Australian study that found that people with a diagnosis other than cancer who received palliative care services were less likely to die in an inpatient setting and more likely to die in the community. ${ }^{29}$ For the NDD group, community-based care can be organized for extended periods, given that there is early warning of increasing nursing and other needs. ${ }^{30}$ Caregivers 
Table 2a. Comparison between People Who had Someone Close to Them Die with a Neurodegenerative Disease (NDD) in the Five Years before Interview and All Other People Who Had Experienced an Expected Death in the Same Time Period from Face-to-Face Whole-of-Population Data in South Australia 2000-2007 (Weighted Data)

\begin{tabular}{|c|c|c|c|c|}
\hline \multirow[b]{2}{*}{ Factor } & \multirow[b]{2}{*}{ Factor reported } & \multicolumn{2}{|c|}{$\begin{array}{l}\text { Someone close died in the } \\
\text { five years before responding of... }\end{array}$} & \multirow[b]{2}{*}{$\mathrm{p}$ value } \\
\hline & & $\begin{array}{l}\text { a neurodegenerative } \\
\text { disease } \mathrm{n}=230\end{array}$ & $\begin{array}{l}\text { another diagnosis } \\
\mathrm{n}=7685\end{array}$ & \\
\hline \multicolumn{5}{|l|}{ Respondent characteristics } \\
\hline \multicolumn{5}{|c|}{ Demographic factors that do not change as the result of someone close dying } \\
\hline $\begin{array}{l}\text { Gender } \\
\mathrm{n}=7915\end{array}$ & Male & $\begin{array}{c}115 \\
50.0 \%\end{array}$ & $\begin{array}{c}3608 \\
46.9 \%\end{array}$ & 0.361 \\
\hline $\begin{array}{l}\text { Age of respondent } \\
\mathrm{n}=7915\end{array}$ & $65+$ & $\begin{array}{l}46 \\
20.0 \%\end{array}$ & $\begin{array}{l}1390 \\
18.1 \%\end{array}$ & 0.459 \\
\hline $\begin{array}{l}\text { Country of birth } \\
n=7915\end{array}$ & non-English speaking & $\begin{array}{c}8 \\
3.5 \%\end{array}$ & $\begin{array}{l}730 \\
9.5 \%\end{array}$ & $0.002^{\#}$ \\
\hline $\begin{array}{l}\text { Highest level of education } \\
\mathrm{n}=7915\end{array}$ & School at most & $\begin{array}{c}115 \\
50.0 \%\end{array}$ & $\begin{array}{c}3682 \\
47.9 \%\end{array}$ & 0.540 \\
\hline $\begin{array}{l}\text { Relationship to the deceased } \\
\mathrm{n}=7915\end{array}$ & Spouse & $\begin{array}{c}5 \\
2.4 \%\end{array}$ & $\begin{array}{l}220 \\
3.3 \%\end{array}$ & $0.689^{\#}$ \\
\hline \multicolumn{5}{|c|}{ Demographic factors that may change as the result of the death of someone close } \\
\hline $\begin{array}{l}\text { Rurality } \\
\mathrm{n}=7915\end{array}$ & Metropolitan & $\begin{array}{c}153 \\
66.5 \%\end{array}$ & $\begin{array}{l}5226 \\
68.0 \%\end{array}$ & 0.635 \\
\hline $\begin{array}{l}\text { Current work status } \\
\mathrm{n}=7009^{*}\end{array}$ & Full or part-time & $\begin{array}{c}113 \\
56.5 \%\end{array}$ & $\begin{array}{c}3863 \\
56.7 \%\end{array}$ & 0.948 \\
\hline $\begin{array}{l}\text { Household income } \\
\mathrm{n}=6888^{\# \#}\end{array}$ & $>$ AU\$60,000 & $\begin{array}{c}73 \\
36.5 \%\end{array}$ & $\begin{array}{c}2405 \\
36.0 \%\end{array}$ & 0.875 \\
\hline \multicolumn{5}{|l|}{ The caregiving role } \\
\hline $\begin{array}{l}\text { Level of hands-on care } \\
\mathrm{n}=7915\end{array}$ & Day-to-day or intermittent & $\begin{array}{c}38 \\
18.5 \%\end{array}$ & $\begin{array}{c}1466 \\
22.1 \%\end{array}$ & 0.227 \\
\hline $\begin{array}{l}\text { Length of time for } \\
\text { which care was given. }{ }^{*} n=1360\end{array}$ & $2+$ years & $\begin{array}{c}22 \\
51.5 \%\end{array}$ & $\begin{array}{c}515 \\
39.1 \%\end{array}$ & 0.111 \\
\hline \multicolumn{5}{|l|}{ After the caregiving role } \\
\hline $\begin{array}{l}\text { Take on caregiving } \\
\text { role again. }{ }^{*} n=491\end{array}$ & Yes & $\begin{array}{c}12 \\
66.7 \%\end{array}$ & $\begin{array}{c}355 \\
76.2 \%\end{array}$ & 0.355 \\
\hline $\begin{array}{l}\text { Perceived unmet needs } \\
\text { identified. }{ }^{*} \mathrm{n}=7915\end{array}$ & Yes & $\begin{array}{c}67 \\
37.0 \%\end{array}$ & $\begin{array}{c}1951 \\
35.2 \%\end{array}$ & 0.842 \\
\hline $\begin{array}{l}\text { Moving on with life* } \\
n=6793\end{array}$ & Have been able to move on with my life & $\begin{array}{c}195 \\
95.6 \%\end{array}$ & $\begin{array}{c}6058 \\
91.9 \%\end{array}$ & 0.058 \\
\hline $\begin{array}{l}\text { Grief* } \\
n=2746\end{array}$ & Sought or wished sought & $\begin{array}{c}21 \\
21.0 \%\end{array}$ & $\begin{array}{c}455 \\
17.2 \%\end{array}$ & 0.324 \\
\hline \multicolumn{5}{|l|}{ The deceased and his/her death } \\
\hline $\begin{array}{l}\text { Place of death* } \\
\mathrm{n}=2720\end{array}$ & Community (home, RACF) & $\begin{array}{c}39 \\
41.9 \%\end{array}$ & $\begin{array}{c}698 \\
26.6 \%\end{array}$ & $0.001^{\wedge}$ \\
\hline $\begin{array}{l}\text { Age of the deceased } \\
\mathrm{n}=2759\end{array}$ & $65+$ & $\begin{array}{c}63 \\
63.0 \%\end{array}$ & $\begin{array}{c}1784 \\
67.1 \%\end{array}$ & 0.393 \\
\hline $\begin{array}{l}\text { Comfort in the last two week } \\
\text { of life.* } n=1857\end{array}$ & Very of comfortable & $\begin{array}{c}19 \\
27.5 \%\end{array}$ & $\begin{array}{c}622 \\
34.8 \%\end{array}$ & 0.214 \\
\hline \multicolumn{5}{|l|}{ Service utilisation } \\
\hline $\begin{array}{l}\text { Palliative care service used } \\
\mathrm{n}=7915\end{array}$ & Yes & $\begin{array}{c}120 \\
51.9 \%\end{array}$ & $\begin{array}{c}3689 \\
48.1 \%\end{array}$ & 0.249 \\
\hline
\end{tabular}

RACF - residential aged care facility.

$\wedge$ Using Bonferroni's correction, the level of significance becomes 0.0028 .

*See Table 1 for the years in which this question was asked.

"Fisher's exact test used.

\#\#1027 declined to provide a response for income.

through this extended period of time become adept at providing complex community-based care.

The emotional distress suffered by caregivers of terminally ill patients with NDD has been documented. ${ }^{16,31}$ Whether this prolonged distress accounts for some of the perceived discomfort in the last 2 weeks of life, or whether the frequently encountered respiratory symptoms are a key driver of this perception cannot be answered from these data. Even before death occurs, families and friends grieve for the loss of function in their loved ones and their own significantly altered future. ${ }^{31}$ In a submission to a consultation on the social impact of caring for terminally ill people, ${ }^{32}$ a caregiver described the grieving process and the emotional strain related to caring for someone with MND: 
...the emotional strain on family members starts well before they become caregivers, for first there is a period of uncertainty, confusion, and worry to negotiate. What follows, however, is a desperate sense of futility: no matter what you, or anyone else does, no matter how hard you try, or how tenderly you look after your loved one, nothing can stop the disease. In the case of motor neuron disease, it means the grieving starts early: as the weeks and months go on, so much is lost that can never be regained.... I also wonder who is most affected by depression... the caregiver or the patient? ${ }^{32}$

Table 2b. Comparison between Active Caregivers of People with a Neurodegenerative Disease

Who had Died in the Five Years before the Interview and All Other Active Caregivers

Who Had Experienced and Expected Death in the Same Time Period from Face-to-Face Whole-of-Population Data in South Australia 2000-2007 (Weighted Data)

\begin{tabular}{|c|c|c|c|c|}
\hline \multirow[b]{2}{*}{ Factor } & \multirow[b]{2}{*}{ Factor reported } & \multicolumn{2}{|c|}{$\begin{array}{l}\text { Someone close died in the } \\
\text { five years before responding of... }\end{array}$} & \multirow[b]{2}{*}{$\mathrm{p}$ value } \\
\hline & & $\begin{array}{c}\text { a neuro } \\
\text { degenerative } \\
\text { disease } \mathrm{n}=55\end{array}$ & $\begin{array}{c}\text { another } \\
\text { diagnosis } \\
\mathrm{n}=1973\end{array}$ & \\
\hline \multicolumn{5}{|l|}{ Respondent characteristics } \\
\hline \multicolumn{5}{|c|}{ Demographic factors that do not change as the result of someone close dying } \\
\hline $\begin{array}{l}\text { Gender } \\
\mathrm{n}=2028\end{array}$ & Male & $\begin{array}{c}21 \\
38.2 \%\end{array}$ & $\begin{array}{c}801 \\
40.6 \%\end{array}$ & 0.719 \\
\hline $\begin{array}{l}\text { Age of respondent } \\
n=2028\end{array}$ & $65+$ & $\begin{array}{c}6 \\
11.1 \%\end{array}$ & $\begin{array}{c}337 \\
17.1 \%\end{array}$ & $0.356^{\#}$ \\
\hline $\begin{array}{l}\text { Country of birth } \\
\mathrm{n}=2028\end{array}$ & non-English speaking & $\begin{array}{c}3 \\
5.5 \%\end{array}$ & $\begin{array}{l}186 \\
9.4 \%\end{array}$ & $0.478^{\#}$ \\
\hline $\begin{array}{l}\text { Highest level of education } \\
n=2028\end{array}$ & School at most & $\begin{array}{c}22 \\
40.7 \%\end{array}$ & $\begin{array}{c}900 \\
45.6 \%\end{array}$ & 0.476 \\
\hline $\begin{array}{l}\text { Relationship to the deceased } \\
n=2028\end{array}$ & Spouse & $\begin{array}{l}5 \\
9.1 \%\end{array}$ & $\begin{array}{c}198 \\
10.0 \%\end{array}$ & $1.000^{\#}$ \\
\hline \multicolumn{5}{|c|}{ Demographic factors that may change as the result of the death of someone close } \\
\hline $\begin{array}{l}\text { Rurality } \\
\mathrm{n}=2028\end{array}$ & Metropolitan & $\begin{array}{c}37 \\
68.5 \%\end{array}$ & $\begin{array}{c}1344 \\
68.1 \%\end{array}$ & 0.951 \\
\hline $\begin{array}{l}\text { Current work status } \\
\mathrm{n}=1694\end{array}$ & Full or part-time & $\begin{array}{c}26 \\
60.5 \%\end{array}$ & $\begin{array}{c}962 \\
58.3 \%\end{array}$ & 0.773 \\
\hline $\begin{array}{l}\text { Household income } \\
\mathrm{n}=1747^{* * *}\end{array}$ & $>$ AU $\$ 60,000$ & $\begin{array}{c}22 \\
36.7 \%\end{array}$ & $\begin{array}{c}620 \\
36.5 \%\end{array}$ & 0.230 \\
\hline \multicolumn{5}{|l|}{ The caregiving role } \\
\hline $\begin{array}{l}\text { Level of hands-on care } \\
n=2028\end{array}$ & Day-to-day or intermittent & $\begin{array}{c}38 \\
69.1 \%\end{array}$ & $\begin{array}{c}1466 \\
74.3 \%\end{array}$ & 0.384 \\
\hline $\begin{array}{l}\text { Length of time for which } \\
\text { care was given. } N=1360\end{array}$ & $2+$ years & $\begin{array}{c}22 \\
51.2 \%\end{array}$ & $\begin{array}{c}515 \\
39.1 \%\end{array}$ & 0.111 \\
\hline \multicolumn{5}{|l|}{ After the caregiving role } \\
\hline $\begin{array}{l}\text { Take on caregiving } \\
\text { role again. }{ }^{*} \mathrm{n}=485\end{array}$ & Yes & $\begin{array}{c}12 \\
70.6 \%\end{array}$ & $\begin{array}{c}355 \\
75.9 \%\end{array}$ & 0.359 \\
\hline $\begin{array}{l}\text { Perceived unmet needs } \\
\text { identified. }{ }^{*} n=2028\end{array}$ & Yes & $\begin{array}{c}21 \\
38.9 \%\end{array}$ & $\begin{array}{c}761 \\
36.4 \%\end{array}$ & 0.704 \\
\hline $\begin{array}{l}\text { Moving on with life } \\
n=2028\end{array}$ & $\begin{array}{l}\text { Have been able to } \\
\text { move on with my life }\end{array}$ & $\begin{array}{c}50 \\
90.9 \%\end{array}$ & $\begin{array}{c}1638 \\
83.7 \%\end{array}$ & $0.192^{\#}$ \\
\hline $\begin{array}{l}\text { Grief* } \\
\mathrm{n}=842\end{array}$ & Sought or wished sought & $\begin{array}{c}13 \\
48.1 \%\end{array}$ & $\begin{array}{c}260 \\
31.9 \%\end{array}$ & 0.076 \\
\hline \multicolumn{5}{|l|}{ The deceased and his/her death } \\
\hline $\begin{array}{l}\text { Place of death* } \\
\mathrm{n}=842\end{array}$ & Community (home, RACF) & $\begin{array}{c}13 \\
54.2 \%\end{array}$ & $\begin{array}{c}267 \\
32.7 \%\end{array}$ & $0.028^{\wedge}$ \\
\hline $\begin{array}{l}\text { Age of the deceased } \\
n=842\end{array}$ & $65+$ & $\begin{array}{c}16 \\
59.3 \%\end{array}$ & $\begin{array}{c}573 \\
70.0 \%\end{array}$ & 0.230 \\
\hline $\begin{array}{l}\text { Comfort in the last two } \\
\text { weeks of life. }{ }^{*} n=515 \\
\text { Service utilisation }\end{array}$ & Very of comfortable & $6.3 \%$ & $\begin{array}{c}199 \\
39.9 \%\end{array}$ & $0.007^{\#} \wedge$ \\
\hline $\begin{array}{l}\text { Palliative care service used } \\
\mathrm{n}=2028\end{array}$ & Yes & $\begin{array}{c}34 \\
61.8 \%\end{array}$ & $\begin{array}{c}1150 \\
58.3 \%\end{array}$ & 0.600 \\
\hline
\end{tabular}

RACF - residential care facility.

"Fisher's Exact Test.

* See Table 1 for the years in which this question was asked.

***A substantial proportion of respondents did not provide a response.

^Using Bonferroni's correction, the level of significance becomes 0.0028 
Table 3. Perceived Unmet Needs in Active Caregiving Role From a Face-to-Face Interview With Bereaved Caregivers in the Five Years after the Death From a Whole-of-Population Survey in South Australia (2002,3, 2005-2007; Weighted DAtA)

\begin{tabular}{|c|c|c|c|}
\hline \multirow[b]{2}{*}{ Factor } & \multicolumn{2}{|c|}{$\begin{array}{c}\text { Carers of someone who } \\
\text { died from... }\end{array}$} & \multirow[b]{2}{*}{$\underset{\text { value }}{\mathrm{p}}$} \\
\hline & $\begin{array}{c}\text { a neuro } \\
\text { degenerative } \\
\text { disease } \mathrm{n}=51\end{array}$ & $\begin{array}{l}\text { another } \\
\text { diagnosis } \\
\mathrm{n}=1675\end{array}$ & \\
\hline \multicolumn{4}{|l|}{ Individual factors } \\
\hline $\begin{array}{l}\text { Help with } \\
\text { physical care, } \\
\text { medications, } \\
\text { symptom control }\end{array}$ & $\begin{array}{c}11 \\
21.6 \%\end{array}$ & $\begin{array}{c}381 \\
22.7 \%\end{array}$ & 0.843 \\
\hline $\begin{array}{l}\text { Information } \\
\text { (about what to } \\
\text { expect, services) }\end{array}$ & $\begin{array}{c}10 \\
19.6 \%\end{array}$ & $\begin{array}{c}303 \\
18.1 \%\end{array}$ & 0.780 \\
\hline $\begin{array}{l}\text { Additional } \\
\text { emotional, } \\
\text { spiritual } \\
\text { or bereavement } \\
\text { support }\end{array}$ & $\begin{array}{c}18 \\
36.0 \%\end{array}$ & $\begin{array}{c}395 \\
23.6 \%\end{array}$ & 0.043 \\
\hline Financial support & $\begin{array}{l}5 \\
9.8 \%\end{array}$ & $\begin{array}{c}99 \\
5.9 \%\end{array}$ & $0.229^{\#}$ \\
\hline \multicolumn{4}{|l|}{ Summary factors } \\
\hline $\begin{array}{l}\text { Had enough } \\
\text { support }\end{array}$ & $\begin{array}{c}17 \\
33.3 \%\end{array}$ & $\begin{array}{c}483 \\
28.8 \%\end{array}$ & 0.485 \\
\hline $\begin{array}{l}\text { Any positive } \\
\text { answer to } \\
\text { additional } \\
\text { support needs }\end{array}$ & $\begin{array}{c}24 \\
51.0 \%\end{array}$ & $\begin{array}{c}822 \\
49.0 \%\end{array}$ & 0.780 \\
\hline
\end{tabular}

"Fisher's exact test used.

Including the provision of emotional support while in the role and subsequently is an important part of palliative care for people with NDD. ${ }^{33,34}$ Several authors have recommended that involvement in palliative care services for people with NDDs should occur relatively early in the course of the illness, anticipating active caregivers' needs well in advance of predictable physical deterioration, and assisting with later stage symptoms, psychosocial issues and decision making about the levels of active clinical intervention. ${ }^{35,36}$ NDD caregivers reported that those who received more tailored services and SPCS input were the most satisfied, highlighting the need for responsive and flexible models of care for people with NDD and their caregivers. ${ }^{11,13}$

\section{Generalizability}

The results reflecting caregiver demographics are likely to be able to be generalised to other settings with similar disease burden to Australia. This would include most nations with similar levels of resourcing for the population's health and social care. Local referral patterns for service uptake cannot be generalized given the local nature of referral patterns related to local clinical champions and service delivery models.

\section{Limitations}

Methods. This study required people to recall their experiences of caring and define whether they were "close" to the decedent and what constituted a palliative care service. It is likely that most caregivers will have excellent recollection of such an important life event and be able to reflect on it honestly and accurately. The respondents' answers however may be tempered by their current emotional state. Those who are "moving on" with their life may have a more positive recollection than those who are not. The fact that there were differential findings in emotional/bereavement domains suggest that this is a group of people whose needs are more prevalent and to which services need to respond in a tailored way.

There is also no objective way of confirming the cause of death from death certificates or other health records. Although there may be some inaccuracy in this, it is likely spread evenly across all diagnostic groups and, given sample size, is relatively negligible.

Sample. As caring is a health risk associated with increased mortality and morbidity, ${ }^{37}$ some caregivers who were particularly vulnerable may not have survived to participate in this population-based survey or were now too unwell. Also, people living in remote South Australia were not part of this survey. As such, there are a small number of people whose needs cannot be reflected in this study.

\section{Implications for practice}

The findings of this study suggest that active caregivers for people with an NDD should have their care needs carefully assessed, particularly in the emotional, spiritual and bereavement domains. Assessment needs to occur while in the role of carer and in the subsequent bereavement phase. Given that the proposed new $D S M-V$ criteria for prolonged grief reaction requires significant time between death and subsequent diagnosis, ${ }^{38}$ the long-term follow-up for people who have provided care for someone with an NDD becomes a specific responsibility for health providers. Relying on selfidentification for support months or years after the death is unlikely to be adequate.

\section{Implications for research}

There is a need for prospective whole of population studies that follow the role of caregivers from the time that they identify a caring role through to the bereavement phase, to help understand the pressures and challenges of the role. If community health and social services are going to better meet the needs of NDD carers, it is imperative that the specific needs of subgroups of caregivers are identified and understood at a population level, with a subsequent response put in place that better addresses these needs. Understanding the cause of perceived discomfort in the last 2 weeks of life is a specific need in future research.

\section{Overall}

This study is the first step in better understanding what is happening across the whole population as people experience the consequences of an expected death from an NDD. The study is unique in that it was not limited by identification through previous access to a specific health service or health practitioner. Unmet needs among self-identified NDD caregivers were clearly identified. This is an important target for service planners, particularly those planning SPCS. 


\section{Acknowledgments}

The authors would like to thank Ms. Debbie Marriott for her excellent work in manuscript preparation and submission. They would also like to thank Harrison Health Research and all the people of South Australia who so willingly participate in these interviews.

Direct costs of this study were provided through discretionary research funds held by Southern Adelaide Palliative Services, Daw Park, South Australia, Australia with supplemental funding from the Daw House Hospice Foundation, Daw Park, South Australia, Australia provided as an unrestricted grant. The Foundation had no input into study conception, design, execution, analysis, or reporting. As such, the researchers are completely independent of the funders.

\section{Author Disclosure Statement}

No competing financial interests exist.

\section{References}

1. Kristjanson LJ, Toye C, Dawson S: New dimensions in palliative care: A palliative approach to neurodegenerative diseases and final illness in older people. Med J Aust 2003; 179:S42-S44.

2. McDermott CJ, Shaw PJ: Diagnosis and management of motor neurone disease. BMJ 2008;336:658-662.

3. Tremlett H, Paty D, Devonshire V: Disability progression in multiple sclerosis is slower than previously reported. $\mathrm{Neu}-$ rology 2006;66:172-177.

4. Figved N, Myhr KM, Larsen JP, Aarsland D: Caregiver burden in multiple sclerosis: The impact of neuropsychiatric symptoms. I Neurol Neurosurg Psychiatry 2007;78:10971102.

5. Chipchase SY, Lincoln NB: Factors associated with carer strain in carers of people with multiple sclerosis. Disabil Rehabil 2001;23:768-776.

6. Kristjanson LJ, Aoun SM, Yates P: Are supportive services meeting the needs of Australians with neurodegenerative conditions and their families? J Palliat Care 2006;22:151-157.

7. Patti F, Amato MP, Battaglia MA, Pitaro M, Russo P, Solaro C, Trojano M: Caregiver quality of life in multiple sclerosis: A multicentre Italian study. Mult Scler 2007;13:412-419.

8. Lo Coco G, Lo Coco D, Cicero V, Oliveri A, Lo Verso G, Piccoli F, La Bella V: Individual and health-related quality of life assessment in amyotrophic lateral sclerosis patients and their caregivers. J Neurological Sci 2005;238:11-17.

9. Rivera-Navarro J, Morales-Gonzalez JM, Benito-Leon J: Informal caregiving in multiple sclerosis patients: Data from the Madrid Demyelinating Disease Group study. Disabil Rehabil 2003;25:1057-1064.

10. Ray RA, Street AF: Non-finite loss and emotional labour: Family caregivers' experiences of living with motor neurone disease. J Clin Nurs 2007;16:35-43.

11. Aoun S, Kristjanson L, Oldham L: The challenges and unmet needs of people with neurodegenerative conditions and their carers. J Community Nurs 2006;11:17-20.

12. Wollin J, Sato A: An international comparison of caregiver burden in multiple sclerosis. Aust J Neurosci 2001;14:21-25.

13. Kristjanson L, Aoun S, Oldham L: Supportive and palliative care needs of individuals with neurodegenerative conditions and their family carers. Int J Palliat Nurs 2006;12:368-377.
14. Ray RA, Street AF: Caregiver bodywork: Family members' experiences of caring for a person with motor neurone disease. J Adv Nurs 2006;56:35-43.

15. Siegal SD, Turner AP, Haselkorn JK. Adherence to diseasemodifying therapies in multiple sclerosis: Does caregiver social support matter? Rehabil Psych 2008;53:73-79.

16. Bolmsjo I, Hermeren G: Conflicts of interest: Experiences of close relatives of patients suffering from amytrophic lateral sclerosis. Nurs Ethics 2003;10:187-198.

17. Courts NF, Newton AN, McNeal LJ: Husbands and wives living with multiple sclerosis. J Neurosci Nurs 2005;37:20-27.

18. Love A, Street A, Ray R, Harris R, Lowe R: Social aspects of caregiving for people living with motor neurone disease: Their relationships to carer well-being. Palliat Support Care 2005;3:33-38.

19. De Judicibus MA, McCabe MP: Economic deprivation and its effects on subjective wellbeing in families of people with multiple sclerosis. I Mental Health 2005;14:49-59.

20. Hughes RA, Sinha A, Higginson IJ, Down K, Leigh PN: Living with motor neurone disease: Lives, experiences of services and suggestions for change. Health Soc Care Community 2005;13:64-74.

21. Wollin JA, Yates PM, Kristjanson LJ: Supportive and palliative care needs identified by multiple sclerosis patients and their families. Int J Palliat Nurs 2006;12:20-26.

22. van Teijingen ER, Friend E, Kamal AD: Service use and needs of people with motor neurone disease and their carers in Scotland. Health Soc Care Community 2001;9:397-403.

23. Currow DC, Ward AM, Clark K, Burns CM, Abernethy AP: Caregivers for people with end-stage lung disease: Characteristics and unmet needs in the whole population. Int J Chron Obstruct Pulmon Dis 2008;3:753-762.

24. Australian Bureau of Statistics: Latest issue 3101.0-Australian Demographic Statistics. Released March 22, 2007. www.abs.gov.au/ausstats/abs@.nsf (Last accessed April 23, 2007).

25. Curtin L, Klein R: Direct standardization (age-adjusted death rates), Statistical Notes, No. 6. Hyattsville, MD: National Center for Health Statistics, 1995.

26. Currow DC, Abernethy AP, Fazekas BS: Specialist palliative care needs of whole populations: A feasibility study using a novel approach. Palliat Med 2004;18:239-247.

27. Wilson DH, Wakefield M, Taylor AW: The South Australian Health omnibus survey. Health Promotion J Aust 1999;2: 47-49.

28. McNamara B, Rosenwax L, Holman C: A method for defining and estimating the palliative care population. J Pain Symptom Manage 2006;32:5-12.

29. McNamara B, Rosenwax L: Factors affecting place of death in Western Australia. Health Place 2007;13:356-367.

30. Oliver D: Palliative care for motor neurone disease. Pract Neurol 2002;2:68-79.

31. Cheung J, Hocking P: Caring as worrying: The experience of spousal carers. J Adv Nurs 2004;47:475-482.

32. The Hardest Thing We Have Ever Done: The Social Impact of Caring for a Dying Person in Australia. Canberra: Palliative Care Australia, 2004. p. 40.

33. Alshubaili AF, Ohaeri JU, Awadalla AW, Mabrouk AA: Family caregiver quality of life in multiple sclerosis among Kuwaitis: A controlled study. BMC Health Serv Res 2008; 8:206.

34. Hebert RS, Lacomis D, Easter C, Frick V, Shear MK: Grief support for informal caregivers of patients with ALS: A national survey. Neurology 2005;64:137-138. 
35. Kiernan MC: Motor neurone disease: A Pandora's box. Med J Aust 2003;178:311-312.

36. Oliver D: Palliative care in amyotrophic lateral sclerosis. J Neurol Sci 2005;238(Suppl 1):S37.

37. Schulz R, Beach S: Caregiving as a risk factor for mortality:/ the caregiver health effects study. JAMA 1999;282:22152219.

38. Prigerson HG, Maciejewski PK: A call for sound empirical testing and evaluation of criteria for complicated grief proposed for DSM-V. Omega 2005;52:9-19.
Address correspondence to: David C. Currow, BMed, M.P.H. Department of Palliative and Supportive Services Flinders University 700 Goodwood Road

Daw Park Adelaide South Australia 5041

E-mail: david.currow@health.sa.gov.au 
